\title{
From specimens, curiosities and illustrations to representatives of the history of art
}

-investigating the role of painting in the display context of the eighteenth century Copenhagen Kunstkammer

\section{BRITTA TøNDBORG}

Paintings and fine art in general have always formed a part of the royal collections in Denmark, but they have not always been perceived in the same way or venerated for the same reasons. This is particularly true of the eighteenth century Kunstkammer where paintings formed an integral part of the encyclopaedic display in the first half of the century, only to be segregated gradually during the second half in order to be placed in the first of a series of specialized galleries of paintings. Two versions of the royal gallery of paintings were installed in the first decades of the nineteenth century; the latter was based on an art historical approach. Most of the paintings in the Kunstkammer survived the transformation from illustrations to fine art, whereas others where deemed unfit candidates for the great survey history of art . ${ }^{1}$

In 1655 the Danish King purchased naturalist Ole Worm's collection of specimens. The Crown's collections then became a mixture of a Renaissance learned collection of specimens and a princely Renaissance Kunstkammer. Between 1665 and 1680 King Frederik III and his successor King Christian V provided a purpose-built three-storey building located in the proximity of the medieval Royal Palace for the collection. The Kunstkammer building, as it was called, contained the whole world under one roof; a plaque on the facade read Ars, Lex et Mars. The Kunstkammer collection was located on the top floor, the Royal Library on the first floor, and the Arsenal or Armoury on the ground floor (Fig. 1). The Kunstkammer consisted of a 70-metre long gallery or corridor with five adjacent galleries; at either end of the long gallery there were two small chambers, and access to the spiral staircases connecting the floors. In 1683-4 a room was added in the attic for the Chamber of 


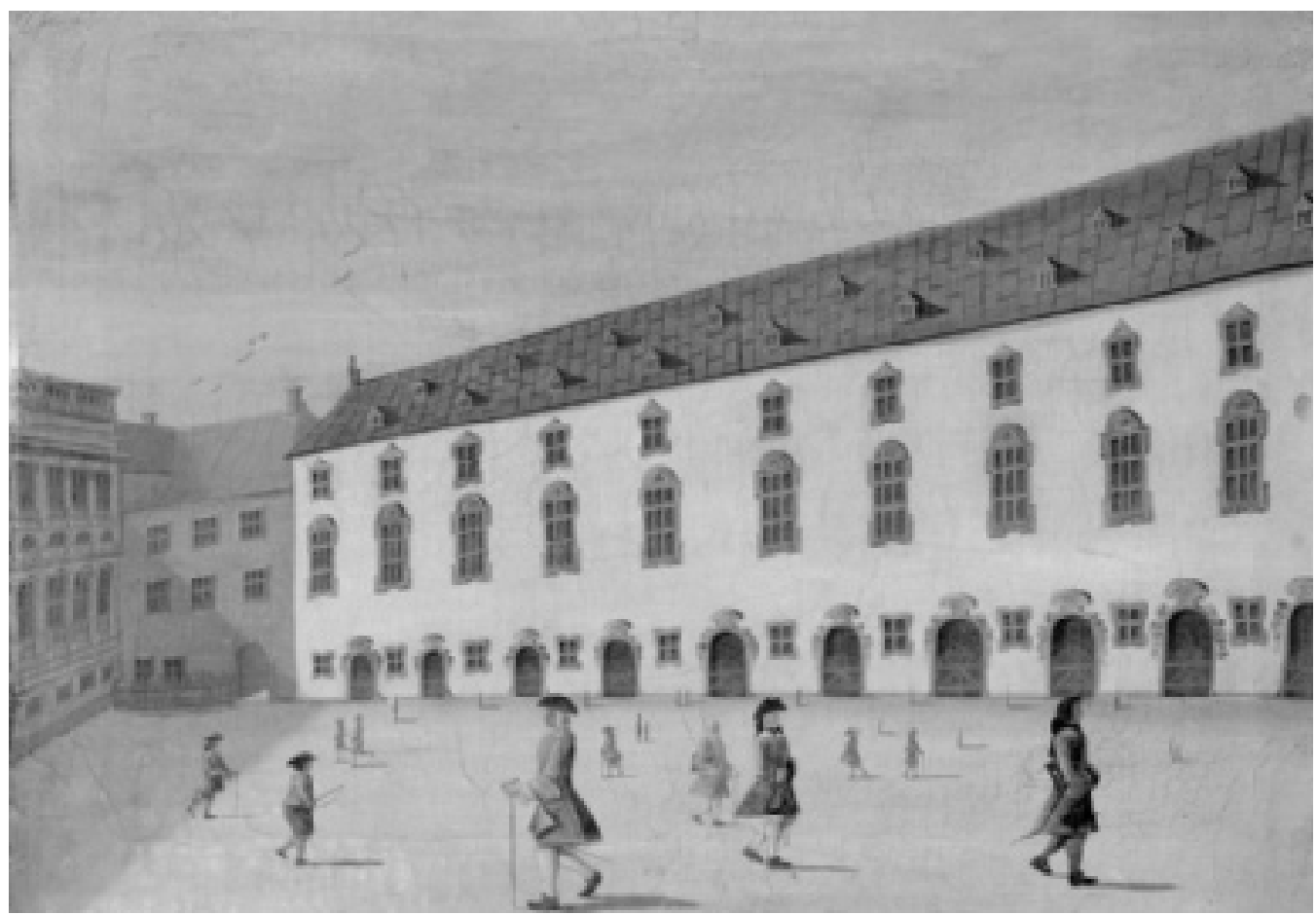

Fig. 1. Rach and Eegberg. The Kunstkammer Building. 1749. () Nationalmuseet. Danmarks Nyere Tid

Models (Gundestrup 1991/95: vol. 1, XIX). In time, rooms in the attic were incorporated to hold parts of the expanding collections.

The inventories give an idea of how the objects were classified and displayed, they list the objects according to the room they were displayed in, and the rooms are named in accordance with their content: Chamber of Natural Objects, Chamber of Artifacts, Indian Chamber, Chamber of Antiquities, Chamber of Heroes, Chamber of Perspectives, Chamber of Models, Chamber of Medals and the long Paintings Gallery.

The Kunstkammer was an encyclopaedic collection, a mirror of the world illustrated by its peculiarities. The objective in the Renaissance collection was to collect the curious and unique as opposed to the typical or representative; the latter ideal was the hallmark of the specialized collections founded in the late eighteenth and the nineteenth century. The collected objects were specimens from nature, curiosities, treasures, mechanical objects, exotic objects and rarities intended for the education and the enjoyment of the Royal Family and the Court, and at the same time the collection functioned as a display of the King's wealth, intended to impress visitors. Importantly the Kunstkammer placed the King at the centre of the world that it encompassed. 
Part of the Kunstkammer was dedicated solely to the display of paintings. The majority were displayed in the 70-metre long gallery, the Gallerie Kammer (Gallery Chamber) where they covered the walls from floor to ceiling; there they provided an impressive tapestry of artistic wealth. The 1737 Kunstkammer inventory has a heading describing it as the "Gallery Chamber, consisting of the works of various famous painters, representing schools both old and new, seascapes, landscapes, paintings of campaigns and battles, historical paintings and the like" (Gundestrup 1991/95: vol. II, 370). This indicates that the paintings in the Gallery Chamber were grouped together in the display according to style of painting or motif - according to school or theme.

Displaying paintings according to school is reminiscent of today's art museum practice, but the Kunstkammer school hang was based on an entirely different approach. Whereas today's school hang is perceived as part of a chronological and topographical approach to perceiving fine art based on a specific narrative i.e. the history of art, an eighteenth century school hang was based on an aesthetic approach. The appearance of the paintings, the style of painting, the tone of colour, bright or dark, the fact that paintings painted in the same style by painters from the same school went well together and their size and shape determined each painting's location in the dense tapestry hangs.

Apart from the display in the Gallery Chamber, paintings were also installed in other parts of the Kunstkammer collection and they were displayed according to approaches that are completely different from today's art historical interpretation. Quite a substantial number of paintings were shown throughout the display in the adjacent chambers, and this practi- ce of displaying art alongside other objects was typical of the Renaissance collection and display ideal. For today's museum goers, paintings would perhaps appear to be out of context if they were displayed along with weaponry and fossils. So what role did fine art play in the Kunstkammer display?

It seems reasonable to say that the key to understanding the role that fine art played in the Kunstkammer is quite straightforward; the key is to use the inventories and perceive the individual works of art as part of their immediate display context. The purpose of the collection was to mirror the world, and fine art played a role in this. The Gallery Chamber aside, it seems that the primary purpose of displaying paintings throughout the Renaissance Kunstkammer was to use them as illustrations. Works of art could be enjoyed in some cases as objects of aesthetic beauty as in the Gallery Chamber, and in other cases paintings served as illustrations to the exotic specimens from faraway places, or the zoological, or the religious objects on display around them. The Renaissance Kunstkammer contained curiosities. Occasionally, a work of art would be regarded as a curiosity in its own right, either because of some special feature like the way it was carved, or as a skilful trompe l'oeil painting that was able to deceive the spectator, or because it depicted a curiosity. The Kunstkammer contained specimens from nature and samples of various materials and substances and therefore art too was occasionally displayed and catalogued as part of this particular category. In the case of paintings, some are listed according to their material and nothing else: oil paintings, watercolours, and so on, as one would catalogue a collection of specimens.

This multi-facetted understanding explains 
why a fine painting by Lucas Cranach depicting Elector Frederic the Wise out hunting (Fig. 2), which is today in Statens Museum for Kunst, was not displayed in the Gallery Chamber, but in the Chamber of Antiquities. According to the 1737 Kunstkammer inventory, the objects on display in this chamber consisted of "a large number of very old antiquities, weapons and instruments of war, curious optical and mechanical inventions, old peculiar pictures and the like" (Gundestrup 1991/95: vol. II, 152). And the Cranach painting is listed in the inventory merely as "A painting in a black frame depicting a deer hunt" (Gundestrup 1991/95: vol. II, 333). In this brief and descriptive entry lies the key to understanding the role that the painting played in the display; it was not displayed there because it was by a famous painter or portrayed another prince exercising his privileges, but because it depicted a hunting scene, and therefore served as an illustration to the display of weaponry around it. The hunting scene filled an illustrative gap in an all-encompassing display organized like Aldrovandi's writings ${ }^{2}$ - all aspects of weaponry were accounted for: the actual objects, and their use illustrated in pictures.

In the same chamber one could find a "Portrait of Moses" and "A Painting in a Wooden Frame, representing Christ, crowned with Thorns and a broken Reed in his Hand, just the way he appeared before King Christian 4th at Rothenburg Castle in the Diocese of Bremen in 1625, ..."A handwritten note by the King describing his vision was inserted in the frame. ${ }^{3}$ The portrait of Christ is today at Rosenborg Castle. These paintings with religious motifs were displayed in the Chamber of Antiquities supplementing the many religious objects in the Chamber. Along with a selection of reliquaries, the religious objects on display here included the alleged belongings of Archbishop and Commander Absalon (1128-1201), said to have founded the city of Copenhagen in the twelfth century. On display were his illuminated prayer book, his chalice, his rapier of gilt brass, his mitre and his parade helmet - and even his skull and two bones.

Apart from the Paintings Gallery, there was one other chamber where fine art formed a substantial part of the display. The Helden Kammer (Chamber of Heroes) display consisted of paintings and sculptures, busts, and wax figures, all portraits of Royalty and famous men and women.

In the Chamber of Medals one could find a substantial numismatic collection, "consisting mostly of ancient and modern coins and medals and also some rare paintings and distinctive portraits" (Gundestrup 1991/95: vol. I, 6). In fact, all the paintings were portraits of mythological or historical figures, but one notes the allusion to their status as 'rare' and 'peculiar', justifying their value and significance as part of the collection. Another reason for displaying the portraits there was, of course, that they complemented the portraits on the coins and medals. This affiliation through motif was severed in later display forms where different types of objects could not be displayed and catalogued together. Today an art historian would group the sculptures according to origin, artist and date and perceive them as part of a historical context.

The portrait busts of Royalty and famous men in the Chamber of Heroes were regarded as portraits, and grouped together as such. The sculptures displayed in the Chamber of Artifacts were included there for an entirely different reason. For this was the "Chamber of 
Artifacts consisting of all sorts of objects made by human art, both in painting and in the art of sculpture, made of silver and other kinds of metal, of bone and of wood, of amber and wax, of straw and paper, of glass and other materials" (Gundestrup 1991/95: vol. I, 212). The sculptures were displayed there because they were classified by the material they were made of, not their motif or the period or school to which they belonged. Paintings too were included in the Chamber of Artifacts, and were listed according to material, not subject matter, genre or school: 'Paintings in oils',
'Paintings in watercolours', 'Drawings in pen and in other materials', and 'Skilfully written objects'. ${ }^{4}$ It is possible that the classification system applied to the Chamber of Artifacts is reminiscent of the system used in Ole Worm's sixteenth-century collection, which was based on material studies and grouped according to material. This approach was phased out entirely in relation to fine art in the nineteenth century; from then on it was no longer possible to perceive an oil painting as a material specimen but only as a work of art. (Mordhorst 2004).

Fig. 2. Lucas Cranach (c. 1472-1553). The stag hunt of Elector Frederic the Wise of Saxony.

Painted after 1529. (C) Statens Museum for Kunst.

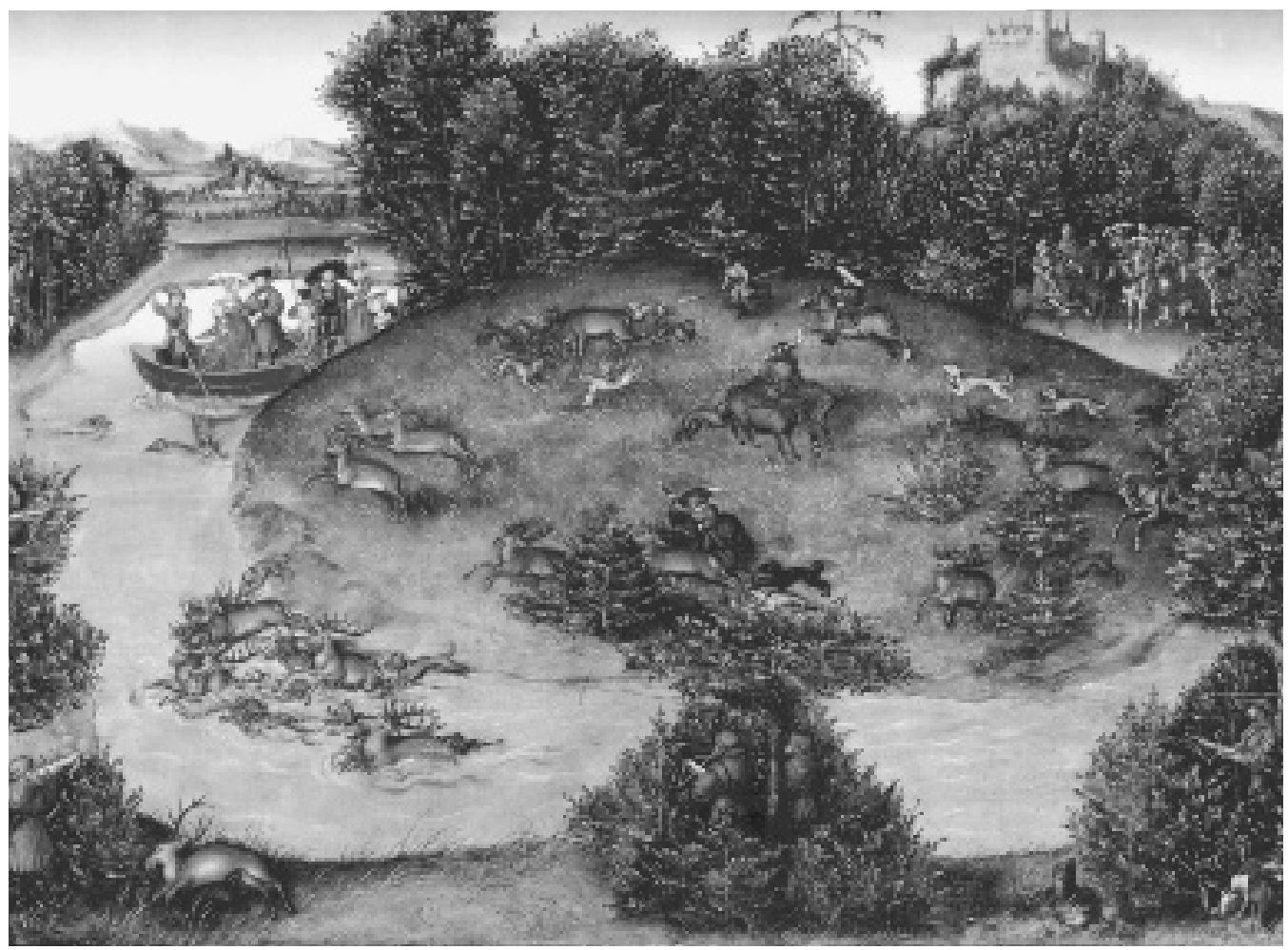


Magnificent trompe l'oeil and still-life paintings by Cornelius Gijsbrechts (c. 1610-1675) and other artists were on display in the Perspective Chamber, along with perspectiveboxes. Here too we find a large prospect of $\mathrm{Pa}$ ris viewed from the Place Dauphine, by Pieter Wouwermans (1623-1682); partly because it is a fine depiction of Paris and the Pont Neuf, but primarily because it is an impressive view. It is quite possible that these paintings were perceived in the same way as other curiosities included in the Kunstkammer. Certainly, in the seventeenth century the general preoccupation with deception and illusion led to the engagement of Gijsbrechts as Court Painter by the Danish King Frederik III and his successor Christian V (1646-1699) (Koester 1999: 17). (See Eva de la Fuente Pedersen's article on Gijsbrechts and the Kunstkammer page 69)

The Danish kings, like other princes, received gifts or funded large expeditions to far-off places, or had officials gather specimens from the Danish colonies, and some of these treasures ended up in the Kunstkammer. Some of the most stunning paintings displayed in the Kunstkammer must have been the life-size in situ renderings of indigenous people from South America by the painter Albert Eckhout (c. 1610-1664). The paintings were presented by Johann Moritz of Nassau to the Danish King Frederik III in 1654. There were Eight large portraits of East and West Indian people in life-size, made in India by Achout (today catalogued as: two full-length portraits of a Tarairiu man and woman, a similar Tupi couple, a portrait of a man from Ghana and a woman and child from Angola), according to the 1737 inventory, and $A$ painting depicting an Indian or Caribbean dance (Dancing Tarairiu). The portraits were supplemented with twelve still-life's of exotic East Indian fruits (Gundestrup 1991/95: vol. II, 125ff). In particular, the full-length portrait of a naked Tarairiu woman holding a sawn-off human hand and carrying a human foot and leg in a basket on her back must have caught the imagination of the visitors to the Kunstkammer, as it still does today (Fig. 3). The paintings were installed in the Indian Chamber, quite naturally illustrating the other exotic objects displayed there, and together the objects offered a selective representation of faraway places.

Unlike the Cranach painting mentioned earlier, the Eckhout paintings were not includ-ed in the Royal collection of paintings in the 1820-30s when the Kunstkammer collection was dispersed. Instead, they went first to the Royal Portrait Collection at Frederiksborg Palace for a brief spell before they were permanently incorporated in the newly founded Det Kongelige Ethnographiske Museum (the Royal Ethnographic Museum), in 1848. And today they still belong to Nationalmuseet in Copenhagen (Gundestrup 2002). These paintings never lost their status as illustrations; they did not suffer the fate of being reclassified as fine art.

Presumably, today's museum visitors still perceive Eckhout's paintings as portraits of native people from a far-off land, just as they were in the Kunstkammer; and for some people today they consequently illustrate a seventeenth-century westerner's perception of the primitive 'other'. Eckhout's paintings have become historical objects reminding us of an era when society went to great lengths to conquer and explore the unknown.

Not all the paintings in the former Kunstkammer survived the transfer from one type of collection to another, from one approach to another. A whole range of paintings or illu- 
FROM SPECIMENS, CURIOSITIES AND ILLUSTRATIONS TO REPRESENTATIVES OF THE HISTORY OF ART

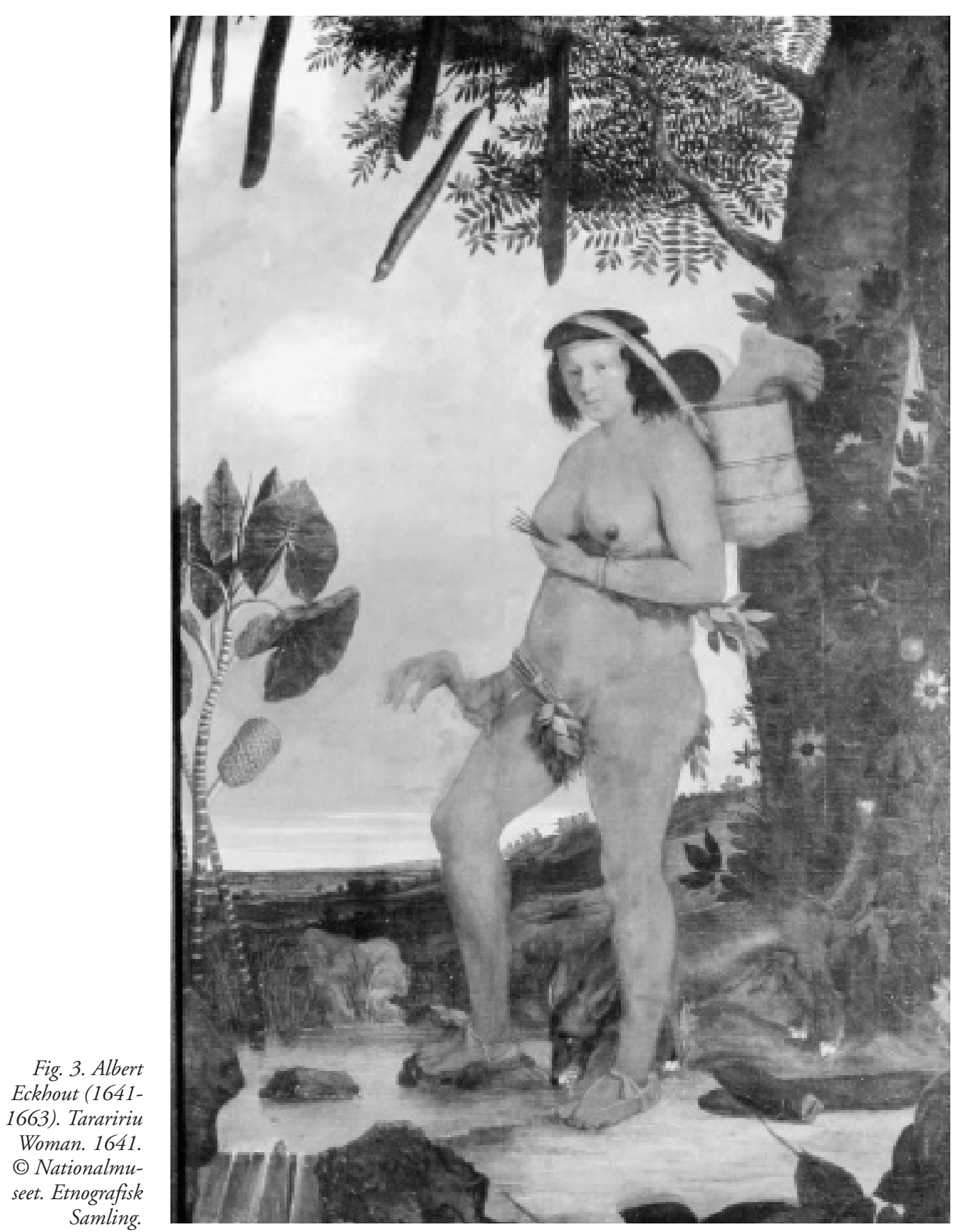


62 strations mentioned in the 1737 inventory were sold at auction in 1824 when the Kunstkammer was dispersed into specialised collections. Apart from two paintings depicting Greenlanders that left the Kunstkammer via the exact same route as the Eckhout paintings mentioned before (Gundestrup 1991/95: vol. 1, 84-85), all eighteen paintings in the former Chamber of Natural Objects were not transferred to a specialised collection, they were all discarded off or sold in auctions, and one can only guess why. According to the 1737 Kunstkammer inventory the paintings in question were titled:

A Picture of the Scythian Lamb. (Missing). (Gundestrup 1991/95: vol. 1 82)

A Painting of a Mackerel-sturgeon, otherwise called Xiphias (ibid. 83)

A Painting of a Deformed Pig born on Amager (ibid. 83)

A Painting of a stuffed Megellanic Goose (ibid. 87)

A Painting on a Chalcedony, Framed (ibid. 87) ${ }^{5}$

A Painting of a Polyp (ibid. 87)

A Painting of a Hind with a small Horn in the Middle of the Forehead (ibid. 87)

A small Painting of a Duck being Caught by a Mussel (ibid. 87)

A Painting of a Harpooner or Whaler named Rejert

Pie, seated at the Line combined with the Whale, which he had to follow three times under the water, and still survived (ibid. 87)

A Painting of 4 Bitter Oranges in super natural size, grown in East India and brought hither (ibid. 88)

A Painting of a pair of curiously large Lemons called Pomelos, grown in the Royal Orangerie at Frederiksberg: 1716 (ibid. 88)

A large Painting of a Mommoneth or a very large Monkey which lived in Copenhagen, and because of its monstrous body was Anatomized in
1610 (ibid. 88. According to Bente Gundestrup, the identification as SMK 1399 is not correct, which means that this painting too could be lost). A large Painting of African Animals (ibid. 88)

A Portrait of a white Cercopith (ibid. 211)

Two Paintings of 2 kinds of Norwegian Fish (ibid. 211)

A small Painting of a Carp with a curiously round head (ibid. 211)

Judging from the titles these paintings depicting curiosities had initially served as illustrations to the other specimens and objects in the Chamber of Natural Objects, and it would seem that they were not needed in the new specialised museums that catered for biology and zoology; they did not appeal to the modern museum founders. Perhaps they would have survived had they lived up to the standards of the eighteenth century draftsmen that meticulously drew specimens of nature, like the comprehensive Flora Danica published between 1761 and 1883. Almost all the curiosities formerly in the Kunstkammer were sold or discarded of in 1824. The hunt was on for the representative specimen and not the unique or peculiar (Mordhorst 2004: 140143).

It is possible that the curiosity paintings would have survived the auction if they had been considered artistically valuable. They would have qualified for a gallery of fine art if they had been assigned to a certain painter or even a school of painting, or if they had lived up to a certain aesthetic ideal. As they could not meet these requirements, they were regarded as lesser works of art and discarded along with the curiosities and other groups of objects that naturally belonged in a Kunstkammer display, but appeared out of place in the new modern museums. 
KÖHLER'S EIGHTEENTH CENTURY GUIDEBOOK ON THE DISPLAY OF PAINTINGS

Our understanding of the different roles that paintings played in the Kunstkammer display has been improved by an eighteenth century handbook for the learned on the organisation of collections of paintings; or rather, the recommendations in the guidebook match the Kunstkammer display. In his 1762 guide Johann David Köhler recommends different approaches to displaying paintings, and it seems that a selection of these approaches were used in the Kunstkammer. Köhler suggests displaying and categorising paintings according to material (wood, canvas, metal, parchment, etc.), which was the case with the paintings allocated to the Chamber of Artifacts. He also suggested organising them according to colour (monochrome or multi-coloured) and subdivided according to material (the wet, the dry, and the burnt colours). Some paintings were catalogued and displayed according to material, but the inventories do not reveal whether they were displayed according to types of colour.

The theme based display is no modern invention. Köhler also suggested his eighteenth century reader should divide a collection of paintings according to their motif or theme:

1) Pictures of people, portraits, etc.

1a) of the living and the dead

1b) love scenes, both dressed and naked scenes

1c) of persons standing

1d) of persons seated

1d) of those lying down, kneeling, with hands, etc.

2) of stories with a lot of people in them. These can be subdivided into three types, into the religious and the secular stories, and the secular into the true or the fictitious stories.
3) of wild and tame animals

4) of landscapes, which are difficult to paint and can also be true or fictitious. Seascapes and paintings of the seasons also belong to this category

5) Perspectives

6) of still-life's, books, foods, instruments

7) Grotesques

In some cases these suggestions were applied in the Kunstkammer display and inventories. The portraits in the Chamber of Heroes was displayed together as portraits, and the perspectives were installed in the Perspective Chamber; and it is possible that the tapestry display in the Gallery Chamber was divided according to subject matter too, or size for that matter, which is the third and final suggestion made by Köhler. Unfortunately, the inventories do not provide a detailed plan of the hang in this particular Chamber, so all we can do is to speculate whether Köhler's suggestion to display the paintings according to motif was applied in the installation. (Köhler $169-171)^{6}$

As for assessing the quality of the paintings Köhler explains to his reader that it is necessary to become acquainted with the masterpieces and the different schools of painting, and he mentions the Italian, the German, and the Dutch schools. (Köhler 1762: 172-173). Köhler also mentions that prints and drawings belong in a collection of paintings, whereas sculpture is included in his chapter on the chambers of Antiquity (Köhler 1762: 145). In the case of the Copenhagen Kunstkammer, sculpture formed part of the display in the Chamber of Heroes as mentioned earlier, and in the Chamber of Artifacts, displayed respectively according to motif, or material and type - just like the paintings.

A large collection of prints and drawings 
64 that dates back to 1521 when King Christian II purchased prints from Albrecht Dürer (1471-1528), formed part of The Royal Library situated on the floor immediately below the Kunstkammer collection. The prints were organised according to theme and mounted in large albums at the time. They primarily served as illustrations supplementing the books and objects in the Kunstkammer. In first decades of the nineteenth century an entirely different organising principle was introduced, the albums were dissolved and the prints and drawings were reorganised according to artist name, based on Johan Adam Bartsch's renowned publication Le Peintre-graveur (18031821), in twenty-one volumes. As a result of this transformation from illustration to work of art, a large selection of prints of lesser artists, copies and so on were left untouched and unnoticed for almost two centuries; until an exhibition was dedicated to trace the fate of the rejects in 2002. (Kofoed Christensen 2002). Similar dispositions were made with regards to the collection of paintings in the first half of the nineteenth century. Here too a selection of copies and lesser works of art were ousted from the collection. Originality, artistic merit and quality became the new decisive factors when art historians selected art works for the displays.

\section{THE SEGREGATION OF PAINTINGS FROM THE KUNSTKAMMER}

The change of approach - from regarding prints and paintings as illustrations, curiosities or specimens of various substances or materials, and as part of a wider Kunstkammer display - to a specialised and more one-sided art history approach, did not happen overnight.
Paintings were not suddenly regarded as a separate entity, which sprang from the laborious task of dividing the Kunstkammer content into specialised collections in the 1820s (Bencard 2000). In fact, the gradual segregation of fine art took place from the mid-eighteenth century to the 1820 s, over a period of half a century. Gradually, during the latter half of the eighteenth century, the status of fine art in the Kunstkammer began to change. At first this change is only perceptible in the Kunstkammer inventories, but soon after a selection of paintings belonging to certain schools of art were segregated from the encyclopaedic Kunstkammer and exhibited in a separate gallery intended only for the display of paintings.

The Kunstkammer inventories reveal how the collection has been classified and displayed through the ages. At the time when art dealer Gerhard Morell (1710-1771) was appointed Kunstkammerforvalter (Keeper), a new approach to classifying the objects in the Kunstkammer was introduced between 1765 and 1775 . Instead of listing the objects according to each Chamber following the display which would group fine art along with other categories of objects, inventory numbers were assigned to the objects acquired after 1737 and they were now divided into categories: (a) painting, (b) antiquities, (c) art objects, (d) ethnographical items, (e) natural objects (Gundestrup 1991/95: vol. 1, XXIV). This meant that paintings throughout the Kunstkammer display were regarded first and foremost as paintings, regardless of their display context and regardless of their former classification context. But this was not all, painting in particular gained status in the latter half of the eighteenth century in Denmark, due to Morell's efforts. 
First, Morell set out to expand the existing collection of paintings and purchased a total of 171 paintings, primarily in Holland, for the Kunstkammer, while employed by the Danish king. Most of his purchases were excellent, and they still make up the nucleus of the collection of old foreign paintings in Statens Museum for Kunst today. Morell purchased masterpieces by Mantegna, Filippino Lippi, Jacob Ruisdael and others (Hertz 1924: 378). Morell's hard work was rewarded in 1759, when he was finally appointed successor to the Kunstkammerforvalter Johan Salomon Wahl, who died in 1765. Morell launched his plan for a new gallery of paintings arranged according to the latest standards by criticising the existing Kunstkammer display.

Morell took the liberty of airing his views on the shoddy and disorderly display of paintings in the Kunstkammer in a letter to the King. He found that the hanging of the paintings in the Kunstkammer was too cluttered and the paintings too ill-matched. The positioning of each painting was not ideal from the viewpoint of the visitor: large-scale paintings should hang on top and paintings standing on the floor, which could only be viewed if one crouched or bent down, should be removed entirely from the display. He considered the venue too narrow for the display of paintings - the ceiling was too low and it was too dark. Morell wrote that the paintings were too numerous and appeared mismatched on the walls; so the only way to introduce a new hanging scheme was to clear the premises and start over: "it reminds me of a wild, dark forest," Morell wrote. ${ }^{7}$ He then suggested an alternative approach that involved segregating all the paintings, both those in the Kunstkammer and his recent purchases, and displaying them together in a setting exclusively dedica- ted to all the paintings in the Kunstkammer. But nothing came of his grand scheme. Instead he made use of the grand corridor connecting the Royal Palace and the Kunstkammer building, called Der Löwen Gang, where he could display a selection of paintings. The word corridor normally means a long narrow space, but after the conversion it became a grand $\mathrm{Ba}$ roque gallery fit for a Royal collection of paintings; and the space itself was actually forty metres long and eleven metres wide, with an impressive five metres to the ceiling (Villadsen, Statens 34). Morell's plan had the added benefit of giving the Court easy access from the Palace to the collection of paintings and to the Kunstkammer building, so the gallery could be used for entertaining guests. The corridor had originally been established when the first Christiansborg Palace was built, replacing the medieval Palace, in 1740-43. The corridor did not grant direct access from the Palace to the Kunstkammer collection; one had to ascend one floor in the Kunstkammer building in order to reach it (Fig. 1). Morell suggested that the gallery should be made accessible not only to the Royal Family and its guests, but also to the students of fine art at the newly founded Royal Academy of Art, so they could copy and learn from the paintings on display.

After two years of hard work, Morell completed the installation of the new gallery in 1764. In 1767 he provided a handwritten catalogue with an attached sketch of the hanging. Only two copies of the handwritten catalogue exist, one for the King, and another one for the Kunstkammerforvalter who needed to keep track of the collection. Morell primarily included paintings that he had purchased himself for the Royal collection in his hanging; paintings by Dutch, Flemish and French 
artists, all schools of painting that were highly appreciated at the time.

Morell's initiatives in fact constituted a change of paradigm. Although the Kunstkammer collection was still displayed according to Renaissance ideals, it could be interpreted and adopted to fit the Enlightenment era and the mode of thought that prevailed in the eighteenth century. This transformation is perhaps most evident in the new taxonomy and the new display context introduced for the paintings in Der Löwen Gang. The Renaissance Kunstkammer administrators wrote inventories of the entire encyclopaedic collection, the Kunstkammer administrator of the Enlightenment age also wrote a catalogue exclusively dedicated to paintings. This illustrates a whole new approach to understanding painting which begins with the segregation of the objects based on their material matter, into a specialized group followed by a subdivision into school based on their style of painting. A taxonomic approach that is reminiscent of Carl Linnaeus' (1707-1778) hierarchical classificatory system invented for classifying living organisms, based on a binominal nomenclature that placed all organisms within the classificatory system of 'genus' and 'species'. After the paintings had been recognised as a member of a certain 'genus' - as fine art or painting, it could be assigned to a range of different species, corresponding with the schools of painting. This was the approach adopted first by Morell, and later by Johan Conrad Spengler (1767-1839), who founded the first specialist gallery of paintings Det kongelige Billedgallerie (The Royal Picture Gallery) after the dispersal of the Kunstkammer collection. Spengler's gallery opened to the public in 1827, and he published the first catalogue raisonné of the collection that same year. Even- tually, the school hang that grouped paintings together according to type and style of painting was adopted and transformed to suit the nineteenth century art history approach. A new dimension was added to the school approach: a chronological narrative that placed all fine art in an evolutionary narrative, the history of art. At the same time the topographical issue related to the schools of painting was emphasised and new historical schools of art were forged and added to the existing, such as Danish Golden Age art. This all constitutes the era of the modern museum, and in Denmark this development was introduced by the first Danish art historian N. L. Høyen (1798-1870). Høyen's version of Det kongelige Billedgallerie opened to the public in 18391840. Due to lack of material Høyen was unable to produce a display that represented the desired chronological survey history of art; instead he had to succumb to a school hang reminiscent of that of his predecessor Spengler.

Painting then, was displayed in three different contexts in Denmark in a one hundred year period from the eighteenth to the midnineteenth century, first, in a Renaissance Kunstkammer along with other types of objects where the paintings were part of a multitude of display contexts making up an encyclopaedic whole. In the Kunstkammer the material and motif could determine the location of the painting in the display, not just the style of painting. Then, secondly, paintings were partly isolated in a habitat of their own in an installation based on eighteenth century thought that provided an interpretative context that applied only to paintings: the paintings were organised and displayed according to schools of painting. The school hang was based on formal qualities such as geographical origin and the style of painting used. Finally, 
paintings were segregated entirely and placed in a one-sided display based on the evolutionary narrative of the history of art, an interpretative context that has survived to present day.

\section{NOTES}

1. The article is in part based on part two of my Ph.D. thesis From Kunstkammer to art museum: Exhibiting and cataloguing art in the Royal collections in Copenhagen, in the eighteenth and nineteenth centuries. Statens Museum for Kunst and The Courtauld Institute of Art, London 2004.

2. Ulisse Aldrovandi (1522-1605). Italian naturalist renowned for his systematic and comprehensive studies of plants, minerals and animals. In his Historia serpentum et draconum all aspects of the serpent and dragon is accounted fore under the headings: "equivocation (which means the various meanings of the word serpent), synonyms and etymologies, differences, form and description, anatomy, nature and habits, temperament, coitus and generation, voice, movements, places, diet physiognomy, antipathy, sympathy, modes of capture, death and wounds caused by the serpent, modes and signs of poisoning, remedies, epithets, denominations, prodigies and presages, monsters, mythology, gods to which it is dedicated, fables, allegories and mysteries, hieroglyphics, emblems and symbols, proverbs, coinage, miracles, riddles, devices, heraldic signs, historical facts, dreams, simulacra and statues, use in human diet, use in medicine, miscellaneous uses." (Quoted in: Foucault 1998: 39)

3. Gundestrup 1991/95: vol. II, 332. The entry includes a concordance and references to previous inventories concerning the Moses portrait. The concordance states that the Moses portrait is in fact a painting by Rembrandt, which today is in Statens Museum for Kunst (Inv. no. SMK1636) entitled Head of an old man in profile. Bente Gundestrup has recently concluded that the portrait of Moses mentioned in the old Kunstkammer inventories from 1674 and 1690 is quite probably not the Rembrandt that is in Statens Museum for Kunst today. SMK1636 has been identified with another painting in The Kunstkammer collection: 1775, 66/a318. The portrait of Christ: Gundestrup 1991/95: vol. II, 264. Rosenborg inv. no. DKK 1.144.

4. Gundestrup 1991/95: vol. I, 358ff, 400ff, 407ff, and $414 \mathrm{ff}$.

5. It is possible that the chalcedony painting was located in this context not because it was a painting or depicted the natural world, but because it was on chalcedony, i.e. it was classified by material and belonged with the natural objects.

6. The Köhler quotes are my translation, the text is summarised.

7. He wrote that "die dortige Gallerie ist schmal, niedrig, dunckel und überfüllt mit Mahlereyen, die Grösse ihre Figuren erschrecken mich in der Nähe, da sie mich in der Ferne ergetzen könten, und das was ich in der Nähe sehen solte, entfernet sich da es auf den Boden stehet und nur durch Knie Beugen von mir betrachtet werden kan, die gar zu grosse Vershiedenheit und überhauffte Menge macht es auch fast unmöglich es je in andere Ordnung zu bringen wenn nicht geräumet wird, und sie kommt mir fast als ein wilder verdunckelter Wald vor, der nicht ehe angenehm wird bis er gelüfftet ist". Quoted in Hertz 1924: 358-390.

\section{BIBLIOGRAPHY}

Bartsch, Johan Adam. Le Peintre-graveur. 21 vol. Vienna, 1803-1821. 
Bencard, Mogens. "Adam Wilhelm Hauch and the Museums". 192-201. Trans. Jean Lundskær-Nielsen. Bencard, Mogens (ed.) Intersections: Art and Science in the Golden Age. Copenhagen: Gyldendal, 2000.

Foucault, Michel. The Order of Things: An Archaeology of the Human Sciences. London: Routledge, (1970) 1998.

Gundestrup, Bente. Det kongelige danske Kunstkammer 1737: The Royal Danish Kunstkammer 1737. Trans. Kirsten R. Solstad, Paulette Møller, Nellie Nissen, Henrik Larsen. Vol. I, II and Index. Nationalmuseet: Ny Nordisk Forlag Arnold Busck, 1991-1995.

Gundestrup, Bente: "The Eckhout paintings and the Royal Danish Kunstkammer. History of the Collection". Albert Eckhout returns to Brazil 16442002. Exhibition catalogue. Nationalmuseet, 103-115. Copenhagen, Denmark 2002. (En revideret udgave er publiceret på dansk i Nordisk Museologi 2004.1)

Hertz, Peter. "Den Kongelige Malerisamlings Tilblivelse." Kunstmuseets Aarsskrift (1921-1923) VIII-X. København, 1924. 358-390.

Hertz, Peter. "Malerisamlingens tilvækst og tilpasning gennem tiderne. Galleriet under Spengler og Høyen's revision." Kunstmuseets Aarsskrift (1924-1925) XI-XII. København, 1926. 290352.

Koester, Olaf. Illusions: Gijsbrechts Royal Master of Deception. Copenhagen: Statens Museum for Kunst, 1999.

Kofoed Christensen, Claes. Hvad kufferten gemte.
Grafik fra de danske kongers samling 1500 1700. København: Statens Museum for Kunst, 2002. (English summary).

Köhler, Johann David. Herrn Professors Johann David Köhlers Anweisung für Reisende Gelehrte, Bibliothecken, Münz-Cabinette, AntiquitätenZimmer, Bilder-Säle, Naturalien- und KunstKammern, u.d.m. mit Nutzen zu besehen. Frankfurt und Leipzig, 1762.

Mordhorst, Camilla. Genstandsfortællinger. Fra Museum Wormianum til de Moderne Museer. Ph.d. afhandling. Roskilde Universitets Center og Nationalmuseet, 2004.

Spengler, Johan Conrad. Catalog over det Kongelige Billedgalleri paa Christiansborg. København, 1827.

Tøndborg, Britta. From Kunstkammer to art museum: Exhibiting and cataloguing art in the Royal collections in Copenhagen, in the eighteenth and nineteenth centuries. Ph.D. thesis. Statens Museum for Kunst og Courtauld Institute of Art, 2004.

Villadsen, Villads. Statens Museum for Kunst 18271952. København: Statens Museum for Kunst \& Gyldendal, 1998.

Curator, ph.d. Britta Tøndborg

Statens Museum for Kunst

Sølvgade

1307 København $K$

E-mail:britta.t@smk.dk 